\title{
Law Enforcement of Criminal Acts of Terrorism Through a Humanist Approach based on Pancasila Law
}

\author{
I Ketut Widhiarto \\ Faculty of Law \\ Lampung University \\ Lampung, Indonesia \\ kintanar4j4@yahoo.co.id
}

\author{
Hieronymus Soerjatisnanta \\ Fakultas Hukum \\ Lampung University \\ Lampung, Indonesia \\ eronymus.soerjatisnanta@fh.unila.ac.id
}

\begin{abstract}
Pancasila, as the source of all sources of state law, is the result of deep exploration, analysis, and reflection by the founding national figures of the Republic of Indonesia. All aspects and values of civilization, history, geography, demography, religion, ethnicity, culture, customs are united in five basic values (grand norm), and each value which is one with other values is an inseparable unity. Terrorism and radicalism are real threats to the existence of Pancasila as an ideology. It takes consistency, awareness, and strong determination from all elements and components of the Nation to replace the ideals of Pancasila law in building every order of national and state life through statutory regulations because Pancasila is the best vaccine in building immunity/deterrence of the Indonesian people from individuals. Radicalism and terrorism and other ideologies. The Pancasila philosophy must continue to be echoed and transmitted in every statutory regulation made, starting from the highest to the lowest provisions, and implemented in the attitudes and legal behavior of the community. This paper was written using the statute approach, the case approach, the historical approach, and the conceptual approach. After the materials have been collected, a study or analysis is carried out using a qualitative prescriptive and normative approach according to the legal issues raised. The purpose of this paper is to present a comprehensive scientific study on the threat of radicalism and terrorism to the existence of Pancasila as the State Ideology and legal philosophy conceptions, placing Pancasila as the source of all sources of state law as reflected in every existing statutory regulation and legal practice to cut the eyes of radicalism and terrorism in Indonesia.
\end{abstract}

Keywords-Flat eyes, Pancasila, Radicalism, Terrorism

\section{INTRODUCTION}

Pancasila is the source of all sources of state law. Pancasila as the ideology and basis of the state, the view of life, and the personality of the Indonesian nation. These conceptions are the philosophical foundation as well as the practical basis for all the people and the Indonesian nation in building a social order and legal ideals to realize the goals of the State [1]. In compiling and controlling the system needed by the state to organize, regulate and organize the survival of the community, regulation or legal order is needed so that every element and existing social institutions can be managed harmoniously. For a country [2].

Terrorism and radicalism are a form of threat to defense and security that are very serious and dangerous for the survival of the nation and state because the threat is aimed directly at the existence of Pancasila as the State Ideology and as the source of all sources of law applicable in the Unitary State of the Republic of Indonesia. From a legal perspective, terrorism and radicalism are inseparable. Radicalism is the fuel (source of energy) that moves anti-Pancasila groups to undermine state sovereignty in the form of terrorism crimes with the ultimate goal of replacing the Pancasila ideology with theirs, and that means destroying the Unitary State of the Republic of Indonesia and replacing the government or regime in power using other methods. Unconstitutional [3].

Crimes of terrorism have very different characteristics from crimes in general. An act of terrorism is carried out systematically, planned, neatly, trained, secret, organized, and involves many individuals, and has a symbolic motive to influence political policy and behavior in extranormal ways [4]. Paul Wilkinson as mentioned by Bijah Subianto, that there are several characteristics of terrorism, namely: coercive intimidation, using systematic killing and destruction, the victim as a means to create a psychological war with a fairly clear message of action, the perpetrators are mostly motivated by 
radical idealism. with the belief to fight for religion and justice [5].

According to Hoffman as quoted by Petrus R. Golose, identifying at least 5 (five) motives for terrorism, namely: 1) Nationalist-Separatist; 2) Religious Ideology; 3) The main issue (single issue); 4) Sponsor country; and; 5) mental disorders (mental disorders). There are examples of terrorism with religious motives such as hard-line Islam such as alQaeda, al-Jama'ah al-Islamiyah (JI), Islamic State of Iraq and Syria (ISIS), or hard-line Hinduism such as the Tamil Tigers in Sri Lanka and Sikhs in India.

From the various terrorist attacks that have occurred in Indonesia since before and after the enactment of Law Number 15 of 2003 concerning the Stipulation of Perppu Number 1 of 2002 concerning the Eradication of Criminal Acts of Terrorism into Law, that the characteristics of terrorism that exist in Indonesia today are terrorism crimes motivated by religion. (religiously motivated), where the perpetrators of criminal acts of terrorism are adherents of radical Islamic ideology which aims to establish the Islamic State of Indonesia (NII). Various terrorist attacks in Indonesia during the last two decades are inseparable from the efforts of a group of radical minorities in continuing and realizing the ideals of the Kartosuwiryo rebellion to establish NII (Darus Islam) and replace Pancasila as the State Ideology in the territory of the Republic of Indonesia [6].

Historically, terrorism and radicalism have emerged in Indonesia since the early days of the independence of the Republic of Indonesia. This legal action has just been declared as a separate offense, namely the criminal act of terrorism in Perppu Number 1 of 2002 concerning the Eradication of Criminal Acts of Terrorism, which is then stipulated as Law Number 15 of 2003. The approach used by the State in handling terrorism continues to change following the demands of social dynamics, the constitutional legal system, and political configurations that evolve [7].

In the early days of independence or the Old Order era, the handling of terrorism was carried out by prioritizing a militaristic approach, then in the New Order era, the handling of terrorism prioritized the Intelligence approach. After the Reformation era, the handling of terrorism used a law enforcement approach. This approach is also in line with UN policy as stated in the Convention for the Prevention and Punishment of Terrorism, November 1937, terrorism is an international crime that can be prosecuted and punished under national law that has jurisdiction over the crime.

The crime of terrorism in Indonesia, which tends for religious motives, has its challenges in dealing with it, including: (1) efforts to eradicate it are dealing with belief as an ideology; (2) the spread of radicalism is systematic and organized in society; (3) the organization can metamorphose; and (4) the handling of terrorism crimes which only focuses on criminal penalties.

Various approaches have been taken in preventing and tackling terrorism crimes by involving various cross-sectoral stakeholders. The causal factors of criminal acts of terrorism are complex, so the approach used is adjusted based on the motives of each person involved in the crime [8]. If the motive for the crime of terrorism is religious reasons, then the law enforcement approach alone is certainly less effective in reducing the number of terrorism crimes. Likewise, if the motive for terrorism is carried out based on reasons of social and economic injustice, the approach that must be taken is a special treatment in the social and economic fields to create a balanced sense of justice.

With the enactment of Law Number 5 of 2018 concerning Amendments to Law Number 15 of 2003 concerning the Stipulation of Perppu Number 1 of 2002 concerning the Eradication of Criminal Acts of Terrorism into Law, juridically, it has a significant impact in law enforcement of criminal acts of terrorism in Indonesia. In the General Explanation it is stated:

To provide a more solid legal basis to ensure legal protection and certainty in the prevention and eradication of criminal acts of terrorism, as well as to meet the legal needs and developments of the community, it is necessary to make changes proportionally while maintaining a balance between the needs of law enforcement, protection of human rights, and socio-political conditions in Indonesia [9].

From the general explanation, there is an emphasis on the paradigm in law enforcement for criminal acts of terrorism, namely the balance between prevention (preventive) and eradication (repressive). Equally important is the non-penal approach related to the fundamental aspects of radical beliefs and antiPancasila ideology from the perpetrators and their families and group members as supporters of acts of terrorism. Because of the criminal justice system (CJS), sentencing is neither the end goal nor the only way to achieve the criminal goals or objectives of the criminal justice system.

Observing legal and socio-political developments during today's society which is dominated by issues of identity politics, intolerance, and radicalism, so this research has a very strategic urgency, both from a legal perspective and from a national perspective in the form of four pillars, namely: 1) Pancasila; 2) the 1945 Constitution of the Republic of Indonesia (UUD 1945); 3) Homeland; and 4) Bhineka Tunggal Ika, with the main issue being "The Legal Conception of Pancasila in Combating Terrorism and Radicalism in Indonesia". There are 2 (two) issues to be discussed, 
namely: 1) how is the reflection of Pancasila as the philosophical foundation in various laws and regulations for countering terrorism and radicalism in Indonesia;

\section{LITERATURE REVIEW}

\section{A. Crime of Terrorism}

Terror and terrorism are two similar words that have recently become popular topics. The term terrorism itself is related to the words terror and terrorist, which generally do not have a standard and universal definition or definition [10]. However, international countries agree that the term has a negative connotation that is equivalent to or equivalent to the term "genocide". Terror is a phenomenon that has quite a long life in history, this is evidenced by the root of the word terror itself, namely the phrase "cimbricus terror". The Romanesque phrase means "to frighten" which describes the panic that occurs when opposing soldiers act fiercely and violently.

Then this word developed for the first time during the French Revolution to become le terreur or terrere which was used when there was brutal violence by beheading many people accused of anti-government activities so that terrorism could be interpreted as liking to intimidate and brutalize civilians with certain reasons. The meaning of terrorism then experienced a shift from what was originally an act committed by an authoritarian ruler with political reasons into the category of crime against state and crime against humanity which resulted in victims of the community of a government so that the political and religious ideals of the terrorists were achieved [11].

In the dictionary of International Relations, it is stated that terrorism is the activity of state or non-state actors who use violent techniques in their efforts to achieve political goals. In line with this understanding, A. Hasnan Habib66 defines terrorism [12]. Terrorism is the use of threats of physical violence that are planned, prepared, and carried out suddenly against direct targets, which are usually non-combatants to achieve a goal. Terrorism involves groups seeking to overthrow certain regimes, correct group or national grievances, or undermine the existing international political order.

Terrorism itself is an act that aims to provide excessive fear through threats or other forms of violence so that not only the injured victims are caused by it, but also the loss of life so that it is evidence of the pressure carried out by groups using terrorist methods [13]. Terror and terrorism are two similar words that have recently become popular topics. The term terrorism itself is related to the words terror and terrorist, which generally do not have a standard and universal definition or definition. According to the national laws of each country, this does not mean eliminating the evil nature of the act and thus means that the perpetrators of terrorism are free from prosecution [14].

Nullum crimen sine poena, the sound of an old legal principle, which means that no crime should be allowed to go unpunished, but the fact that terrorism is an Internationally Organized Crime makes it very difficult to eradicate this type of crime without the cooperation and common understanding among the state country [15].

\section{B. Law Enforcement Concept}

Law enforcement is the process of making efforts to enforce or function legal norms as guidelines for behavior in traffic or legal relations in social and state life. What people mean by law enforcement so far seems to only focus on the repressive actions of law enforcement officers in carrying out firm reactions to the prosecution of criminals [16].

The meaning of law enforcement in this way is very narrow because the authority of law enforcement only seems to be the responsibility of law enforcement alone. Law enforcement in a broad context is in the realm of real or factual actions, actions, or behaviors that are following binding rules or norms. However, to maintain and restore order in social life, the government is the security actor.

Viewed from the point of view of the subject, law enforcement can be carried out by a broad subject and can also be interpreted as an effort to enforce the law by the subject in a limited or narrow sense. In a broad sense, the law enforcement process involves all legal subjects in every legal relationship [17]. Anyone who applies normative rules or does something or does not do something based on the norms of the applicable law means that he is carrying out or enforcing the rule of law. In a narrow sense, in terms of the subject, law enforcement is only defined as the efforts of certain law enforcement officials to guarantee and ensure that a rule of law runs as it should. In ensuring the enforcement of the law, if necessary, law enforcement officials are allowed to use force.

In a broad sense, law enforcement also includes the values of justice contained in the sound of formal rules as well as the values of justice that live in society. However, in a narrow sense, law enforcement only concerns the enforcement of formal and written regulations. Therefore, the translation of the word 'law enforcement' into Indonesian uses the word 'law enforcement in a broad sense, and the term 'rule enforcement can also be used in a narrow sense.

\section{RESEARCH METHODS}

Research has another term or known as research. The research comes from English, namely research which comes from the word re (re) search (search) this research which has the term research can be interpreted as searching again. This research activity is based on the curiosity of someone who is then referred 
to as a researcher in carrying out research activities. Research is a form of expression of curiosity carried out in the form of scientific research activities. This research is carried out with a sense of trust in the object being researched by finding out the causes and effects that arise or occur in the object of research.

This study uses a normative research method. According to Peter Mahmud Marzuki [14], normative legal research is a process to find a rule of law, legal principles, and legal doctrines to answer the legal issues faced. In this type of legal research, the law is often conceptualized as what is written in legislation or the law is conceptualized as a rule or norm which is a benchmark for human behavior that is considered appropriate.

Based on the problem approach and the required data sources, the data collection in this study was carried out through a literature study by reading, quoting, taking notes, and identifying data that was following the problem, and collaborating with the data of applicable laws and regulations. After collecting data, then processing the data obtained is used to analyze the problems studied. Data processing in this study was carried out by Data examination, classification, and data compilation.

\section{RESULTS}

\section{A. Pancasila as the Philosophical Foundation in various laws and regulations in countering Terrorism and Radicalism}

Pancasila as the view and personality of life in the nation and state in the last two decades has experienced a very sharp degradation, this is due to several aspects, such as 1) the existence of a reformation euphoria which considers all the life structures of the nation and state that were built during the New Order government did not exist. need to maintain again; 2) the flow of cultural globalization due to advances in communication and information technology, has removed territorial barriers from one country to another (borderless), causing the life of the nation and state to be very liberal; 3) the existence of fundamentalist groups who want degradation and discredit the ideology of Pancasila and its government system as the cause of the state's failure to realize its goals [18].

The phenomenon of degradation of the practice of Pancasila values and the application of values that highlight identity politics does not only appear in the interaction of social relations and public policies but has infiltrated the legal political order in various laws and regulations. From a legal perspective, the phenomenon that occurs is certainly very dangerous because it has deviated far from the conception of the basic principles of universal law and the ideals of Pancasila Law [19].
The objectives of the Unitary State of the Republic of Indonesia are [20]: 1) to protect the entire Indonesian nation and the entire homeland of Indonesia; 2) promote the general welfare; 3) educate the nation's life; 4) implement world order based on: (a) independence, (b) eternal peace, and (c) social justice. According to Franz Magnis Suseno, as quoted by Agus Riwanto, the conception of the state's moralpolitical goals requires a state to run by using the law as a guideline because it will have several ethical arguments, namely: 1) for the sake of legal certainty; 2) demands equal treatment; 3) the legitimacy of democracy, and 4) the demands of reason.

The counter-terrorism and radicalism approach as the strategy and policies carried out by the National Counterterrorism Agency (BNPT) is a hard approach through repressive measures in the form of law enforcement and a soft approach through prevention (preventive) in the form of national preparedness programs, deradicalization and counter-radicalization [21]. The general principles as a strategic framework used by BNPT in countering terrorists include: 1) The rule of law; 2) Discrimination; 3) Independence; 4) Coordination; 5) Participation; and 6) Democracy.

In the General Elucidation of Law Number 5 of 2018, that to ensure legal protection and certainty in: 1) prevention and 2) eradication of criminal acts of terrorism; 4) meet the needs and legal developments of the community; 5) changes are made proportionally, with; 6) maintain a balance between the need for law enforcement, protection of human rights; and socio-political conditions in Indonesia [22]. Prevention in the form of deradicalization is a planned, integrated, systematic, continuous process that is carried out to eliminate or reduce and reverse the understanding of radicals and terrorism that has occurred.

There are various types and hierarchies of laws and regulations, ranging from MPR Decrees, Laws/Perppu, PP, Presidential Regulations, Provincial Regulations, to Regency/City Regional Regulations. The distribution is an indicator of the complexity of the threat of radicalism and the impact that acts of terrorism can have on the joints of people's lives and state sovereignty.

The reflection of Pancasila in various laws and regulations in countering terrorism and radicalism, in the perspective of law enforcement includes a legal approach with punishment (penal) and a legal approach without punishment (non-penal) [23]. The legal principles or principles that form the basis for sentencing (penal), are conceptually contained in the articles of the Criminal Code and the Criminal Procedure Code, including the principle of legality (nullum delictum nulla poena sine praevia lege), the 
principle of equality before the law (equality before the law). ), the universal principle, the territorial principle, the personality principle, the protection principle, the principle of open court justice, the opportunity principle, the presumption of innocence and presumption of guilt, for the sake of justice and based on the Almighty God (pro justitia), and some other legal principles or principles.

All of the principles or legal principles adopted when examined through the values contained in Pancasila are essentially a reflection of the values from the first precepts to the fifth precepts, where this can be tested using empirically comprehensive steps, systematic, rational-objective, analytical, and verification [24].

In article 15 of Law Number 12 of 2011 concerning the Establishment of Legislations, it is explained that following the hierarchy, laws, and regulations that contain criminal provisions (penal) in the form of imprisonment or fines are only regulated in the form of Laws, Provincial Regulations and Regency Regulations. It was further emphasized that every material content in the formation of laws and regulations must be based on principles; 1) shelter; 2) humanity; 3) nationality; 4) kinship; 5) archipelago; 6) Bhinneka Tunggal Ika; 7) justice; 8) equal position in law and government; 9) order and legal certainty; and 10) balance, harmony, and harmony. All of these principles textually reflect the values of Pancasila,

Explained that the recognition and protection of human rights or citizens in the Preamble and Body of the 1945 Constitution shows that the Indonesian state is a democratic legal state because socio-legally and socio-culturally the existence of a constitution is a consequence of implementing the principles of the rule of law and the principles of a democratic state.

One of the non-penal countermeasures for terrorism and radicalism is a preventive approach in the form of activities such as 1) improving the social and economic conditions of the community; 2) increasing awareness of the law and community discipline, and 3) improving moral education. The purpose of preventive efforts is to motivate, guide, and direct the public about the dangers of terrorism and radicalism so that people are aware of the consequences of criminal penalties and social punishments that will be received if they commit a crime of terrorism. Another objective of preventive efforts is to make the public aware to protect themselves from co-optation of radical groups and terrorism.

Therefore, the non-penal legal approach in countering terrorism and radicalism is essentially a Pancasilaist legal approach that puts forward preventive measures based on the principles of humanity, expediency, protection, openness, kinship, harmony, non-discrimination, justice, consultation. , unity, nationality, and the embodiment of nature as creatures created by God Almighty.

The substance of the non-penal law enforcement approach is unknown in Law Number 5 of 2018 concerning Amendments to Law Number 15 of 2003 concerning the Stipulation of Perppu Number 1 of 2002 concerning the Eradication of Criminal Acts of Terrorism into Law, as well as with the conception of diversion and restorative justice in the system. Juvenile Justice has not reached the efforts of nonpenal law enforcement approaches for terrorism crimes committed by children. Currently, non-penal law enforcement in the prevention of criminal acts of terrorism and eradication of radicalism, in practice, is carried out before the perpetrators enter the criminal justice system or through a preventive and preemptive approach to intelligence operations.

\section{B. The concept of Pancasila law that can break the chain of terrorism and radicalism}

The forms of the concept of prevention in countering terrorism include [25]: 1) national preparedness; 2) deradicalization, and 3) counterradicalization. BNPT as the leading sector, designed deradicalization as a form of prevention through four approaches, namely: first, re-education; second rehabilitation; third resocialization; fourth reintegration. The four approaches are actualized in the form of a humanitarian approach, nationalism, economic empowerment, education, and psychological counseling for the perpetrators and their families. Counter-narrative and counterpropaganda programs through social media are some other forms of counter-radicalism that are carried out in breaking the chain of radicalism.

Deradicalization refers to the US sense. Hikam has two meanings, namely disconnecting or breaking away (disengagement) and deideologizing (deideologization). Disengagement is an effort that leads to behavior change, for example getting out of the attachment of a terrorist network group by changing behavior and life habits, to leaving all the rules of a terrorist group. Furthermore, deideology was continued by eliminating the ideological understanding of the political doctrine of radical Islam, becoming an Islam that upholds the noble values of spreading peace. Deradicalization orientation is changing a person's spectrum from radical to moderate.

In the perspective of Pancasila law, deradicalization efforts can be implemented through the values of Pancasila which are realized in a bottom-up manner by exploring and re-elevating the 
conception of local wisdom that is in line with Pancasila (inductive deradicalization), while topdown is done by positioning the state as the leading sector-main) to socialize the values of Pancasila through statutory instruments that can bind and create an equitable distribution of community welfare, as well as motivate every citizen to maintain and foster an attitude of harmony, tolerance, and cooperation in the process of achieving national goals (deductive deradicalization) [26].

The synergy of the two methods is expected to increase the resilience of the Pancasila ideology in the face of global ideological threats in the form of issues that provoke terrorism and radicalism activities, this method will also encourage the state and society to be able to prevent acts of radicalism through the implementation of Pancasila values transformative deradicalization) [27].

Conceptions carried out through economic, ideological, and other firms tend to be temporary diversions. The form of conception of the national approach and nationalism of Pancasila values is much more effective which is manifested in positive activities at the behavioral level. The integration of the implementation of Pancasila values into the deradicalization method is very important because it will touch the level of values, norms, and behavior of individuals which will then provide a multiplier effect in the form of creating a tolerant society, mutual respect, mutual assistance, and cooperation.

The concept of transformative deradicalization with the implementation of Pancasila values will create output in the form of people who know their identity and character as the Indonesian nation [28]. The ideology of Pancasila will be firmly practiced as a living ideology and working ideology so that people are more rational in facing all challenges of social change and the development of advances in communication and information technology. The radical ideology that occurs today creates hopelessness and irrationality for society in every social change and globalization. The very tight competition between individuals, groups and a very destructive environment creates an unhealthy and unbalanced competition that creates anarchist, intolerant, and radical traits that are far from the values of Pancasila.

The government must be able to provide an example through the reflection of Pancasila values in managing social, legal, economic, and behavioral orders as well as spearheading decision making. Continuing political education can form a participatory political culture of the society in building the nation and state in realizing the goals of a welfare state based on Pancasila.

\section{CONCLUSION}

Pancasila as the source of all sources of state law, at the philosophical level as well as at the practical level with its five precepts is an inseparable unit as a basis in realizing the ideals and goals of the state as stated in the fourth paragraph of the Preamble to the 1945 Constitution. In the perspective of countering radicalism and terrorism, Pancasila is a reflection of the conception of the basic principles of legislation related to countering terrorism and radicalism, both based on the type and hierarchy of laws and regulations from the highest, namely the 1945 Constitution, MPR Decree, UU/Perppu, PP, Perpres, provincial regulations, up to district and city regulations. The conception of the law enforcement approach used in countering terrorism and radicalism, both in the form of the conception of a repressive law enforcement approach (action) and the conception of a preventive approach (prevention) in the form of national preparedness, deradicalization, and counterradicalization. Pancasila is a comprehensive approach that can provide more substantial conceptions in countering terrorism and radicalism. It is necessary to reformulate Pancasila in the life of the nation and state due to the degradation of Pancasila values after the reform era so that the immunity of the Indonesian nation and people in the form of a national ideology that breathes Pancasila will be able to stem radicalism and other ideologies as a negative impact of the swift currents of globalization.

\section{REFERENCES}

[1] Ali, Mahrus, 2012, Criminal Law of Terrorism Theory and Practice, Bekasi, Gramata Publishing.

[2] Ali, Zainuddin Ali, 2018, Legal Research Methods, Jakarta, Sinar Graphic.

[3] Golose, Petrus Reinhard, 2009, Deradicalization of Terrorism, Humanism, Soul Approach and Touching Grassroots, Jakarta, YPKIK.

[4] HS, Salim, Erlies Septiana, 2018, Application of Legal Theory in Dissertation and Thesis Research, Depok, PT. RajaGrafindo Persada, 3rd Edition.

[5] Mbai, Ansyaad, 2014, New Dynamics of Terror Networks in Indonesia, Jakarta, Squad Publishing.

[6] Marzuji, Peter Mahmud Marzuki, 2019, Legal Research, Jakarta, Prenadamedia Group, Revised Edition.

[7] Mahfud MD, 1998, Political Law in Indonesia, Jakarta, LP3ES Library.

[8] Mahfud MD, 2006, Building Legal Politics, Upholding the Constitution, Jakarta, Indonesian LP3ES Library.

[9] Shadly, Hasan, Jhon M Echol and Hasan Shadly, 1975, English - Indonesian Dictionary, Jakarta, Gramedia.

[10] Tanamas, Zulchaina Z, 2015, The Concept of the State of Law, Bandung, Citra Aditya Bakti.

[11] Elviandri, et al, 2019, Journal of the Legal Pulpit Vo.31 No.2, Qua Vadis of the Welfare State, Affirming the Ideology of the Welfare State of the Indonesian Welfare State.

[12] Huda, Muhammad Chairul, 2018 Journal of the Revolution Vol.1 No.1, Affirming Pancasila as the Ideology of the State; 
Implementation of Balanced Values in Legal Development Efforts in Indonesia.

[13] Indrawan, Jerry, et al, 2019, Journal of Defense and State Defense Vol.9 No.2, Effectiveness of the BNPT Deradicalization Program against Terrorism Convicts in Indonesia.

[14] Kurniawan, Syukri, et al, 2020, Journal of Yustisiabel Vol.4 No.1, Non-Penal Efforts in Combating Criminal Acts of Terrorism with the Deradicalization Program in Indonesia.

[15] Luthan Salman Luthan, 2007, Journal of Law Ius Quai Iustum Vol.14 No.2, Legal Relations and Power.

[16] Setiawan, Iwan, et al, 2019. Surya Masyarakat Journal Vol1 No.2, Prevention of Radicalism Movement through Planting Pancasila Ideology and Community-Based Constitutional Awareness Culture.

[17] Mukhtar, Sidrathata, 2016, Journal of Reform Vol.6 No.2, Strategy of the Government of Indonesia to Face Terrorism in the Era of Democratization.

[18] Octadela, Miranda, 2019, Jurist-Diction: Vol. 2 No. 4, Children under the age of 12 who are involved in criminal acts of terrorism.

[19] Rosana, Ellya, 2018, TAPIs Journal Vol.12, No.1, Democratic State and Human Rights.

[20] Surajiyo, et al, 2017, Journal of LPPM Unindra Vol.1 No.1, Scientific Knowledge Structure and Scientific Attitude of Scientists.

[21] Suntoro, Agus, 2020, Journal of the State of Law, DPR-RI, Vol.11 No.1, Application of Human Rights Principles and
Norms in the Law on the Eradication of Criminal Acts of Terrorism.

[22] Sendari, Ayu, 2019, Journal of Media Vol.14 No.2, State Goals of the Republic of Indonesia.

[23] Subianto, Bijah, 2012, "Transparency and Public Accountability in Intelligence Relating to Crimes of Terrorism", paper presented in the National Seminar on the Nature and Criminal Policy of Terrorism Crimes, Faculty of Law, University of Surabaya, 12-22 May 2003, pp 4-5 in Mahrus Ali , Criminal Law on Terrorism Theory and Practice, Gramata Publishing, Bekasi.

[24] Rosadi, Otong, 2018, Pagar Ruyung Law Journal, Vol.1 No.2, The Idea of the State in the Indonesian Constitution: Reconstruction of the 1945 Constitution of the Republic of Indonesia Post-amendment.

[25] Suhaeni, Eni, 2018, UNIS Journal, Vol.18 No.2, Functions of the Family, Society and Government in the Educational Process.

[26] Soenarsono, Maleha, 2007, Journal of Law and Development Vol. 37 No. 2, Indonesia's rule of law in terms of the Theory of State Goals.

[27] Winarni, Luh Nila, 2016 DIH, Jurnal Hukum, Vol.12 No.23, Non-Penal Criminal Law Policy in Combating Crimes of Radicalism in the Form of Terrorism

[28] Wicaksono, Reda, 2015, Journal of UTA45 Jakarta Vol.1 No.2, Implementation of Pancasila Values in the Reformation Era in Preventing the Development of Acts of Radicalism. 